DOI https://doi.org/10.15589/znp2021.3(486).7

УДК 004.82:519.816

\title{
FORESIGHT RESEARCH IN THE PROBLEMS OF CHOOSING THE COMPOSITION OF THE UKRAINIAN NAVY BASED ON THE METHOD OF ANALYSIS OF HIERARCHIES
}

\section{ФОРСАЙТ-ДОСЛІДЖЕННЯ У ЗАВДАННЯХ ВИБОРУ СКЛАДУ ВМС УКРАЇНИ НА ОСНОВІ МЕТОДУ АНАЛІЗУ ІЄРАРХІЙ}

\author{
Tetyana A. Farionova ${ }^{1}$ \\ tetyana.farionova@nuos.edu.ua \\ ORCID: 0000-0003-3384-4712 \\ Igor I. Kovalenko ${ }^{2}$ \\ ihor.kovalenko@chmnu.edu.ua \\ ORCID: 0000-0003-2655-6667 \\ Alona V. Shved ${ }^{2}$ \\ avshved@chmnu.edu.ua \\ ORCID: 0000-0003-4372-7472 \\ Yevhen O. Davydenko ${ }^{2}$ \\ davydenko@chmnu.edu.ua \\ ORCID: 0000-0002-0547-3689
}

\author{
Т. А. Фаріонова ${ }^{1}$, \\ канд. техн. наук, доцент
}

І. І. Коваленко ${ }^{2}$, доктор техн. наук, професор

\author{
А. В. Швед ${ }^{2}$, \\ канд. техн. наук, доцент \\ Є. О. Давиденко ${ }^{2}$, \\ канд. техн. наук, доцент
}

\author{
Admiral Makarov National University of Shipbuilding, Mykolaiv ${ }^{1}$ \\ Національний університет кораблебудування імені адмірала Макарова, м. Миколаїв \\ Petro Mohyla Black Sea National University, Mykolaiv ${ }^{2}$ \\ Чорноморський національний університет імені Петра Могили, м. Миколаїв
}

\begin{abstract}
The most important function of any state is to strengthen military security, which is determined by the state of the country's defense capabilities and its ability to ensure the protection of national interests by means of armed struggle. In this regard, defense construction is an important component of the country's military security is determined by a number of factors, which include both quantitative and qualitative parameters of the navy. A feature of FORSIGHT technologies as a tool to solve forecasting problems is the use of methods that are not quantitative but qualitative. The number of publications on the application of FORSIGHT technologies in the field of defense is small and their content is limited mainly by a general description of the capabilities of such technologies without detailed consideration of specific examples. The purpose of this work is to consider the use of FORSIGHT technologies to solve the problem of selecting the composition of the Ukrainian Navy using the method of analysis of hierarchies. Among the methods of multicriteria scenario analysis, the most widely used in FORSIGHT technologies were the method of hierarchy analysis and the method of analytical networks, developed by T. Saati. The authors based on the "Strategy of the Naval Forces of the Armed Forces of Ukraine 2035", modern concepts of revival of the fleet, the composition of boats and ships of the Ukrainian Navy, their technical characteristics, built four three-level hierarchies (by the number of factors BENEFITS, OPPORTUNITIES, COSTS). As alternatives (A) were the types of boats and ships: $\mathrm{A}_{1}-$ river armored boat "Gyurza", $\mathrm{A}_{2}$ - assault boat "Centaur", $\mathrm{A}_{3}$ - small patrol boat "Island", $\mathrm{A}_{4}$ - high-speed patrol boat "Lan", $\mathrm{A}_{5}$ - rocket boat "Vespa", $\mathrm{A}_{6}$ - multi-purpose corvette "Gaiduk", $\mathrm{A}_{7}$ - small corvette "Caracal". Based on the analysis, priorities were obtained (types of boats and ships), indicating the dominance of alternatives: $\mathrm{A}_{5}$ - rocket boat "Vespa", $\mathrm{A}_{6}$ and $\mathrm{A}_{7}$ - corvettes "Gaiduk" and "Caracal". This in turn leads to the conclusion that the revived fleet should include both boats and corvettes, which will provide the most effective solution to the problems of defense of maritime borders. The scientific novelty of the obtained results is that for the first time an approach based on FORSIGHT technologies was used to solve the problem of further development of the Ukrainian Navy. The practical significance of the obtained results is that the proposed approach can be used to solve the problems of defense construction in the conditions of existing poorly structured problems and uncertainties.

Key words: foresight technologies; method of analysis of hierarchies; choice of composition of the Ukrainian Navy; scenario modeling; criterion; alternative.
\end{abstract}




\section{КОМП'ЮТЕРНІ НАУКИ ТА ІНФОРМАЦІЙНІ ТЕХНОЛОГІЇ № 3-2021}

Анотація. Найважливішою функцією діяльності будь-якої держави є зміцнення військової безпеки, яка визначається станом обороноздатності країни та їі можливістю забезпечити захист національних інтересів засобами збройної боротьби. У зв'язку з цим оборонне будівництво виступає важливим компонентом військової безпеки країни і характеризується цілою низкою факторів, які складаються з кількісних та якісних параметрів військово-морських сил. Особливістю ФОРСАЙТ-технологій як інструменту для вирішення завдань прогнозування $є$ використання методів, що мають не кількісний, а якісний характер. Кількість публікацій, присвячених питанням застосування ФОРСАЙТ-технологій в оборонній сфері, невелика, їх зміст обмежений переважно загальним описом можливостей таких технологій, без детального розгляду конкретних прикладів. Метою роботи $\epsilon$ аналіз використання ФОРСАЙТ-технологій для вирішення завдань вибору складу ВМС України за допомогою методу аналізу ієрархій. Серед методів багатокритеріального аналізу сценаріїв найбільш широке застосування в ФОРСАЙТ-технологіях отримали метод аналізу ієрархій і метод аналітичних мереж, розроблені T. Сааті. Авторами на основі «Стратегії Військово-морських сил Збройних сил України-2035», сучасних концепцій відродження флоту, складу катерів і кораблів ВМС України, їх технічних характеристик було побудовано чотири трирівневі ієрархії (за кількістю таких факторів, як ВИГОДИ, МОЖЛИВОСТІ, ВИТРАТИ, РИЗИКИ). Альтернативою (А) стали типи катерів і кораблів: $\mathrm{A}_{1}$ - річковий броньований катер «Гюрза», $\mathrm{A}_{2}-$ десантно-штурмовий катер «Кентавр», $\mathrm{A}_{3}$ - малий патрульний катер «Island», $\mathrm{A}_{4}$ - швидкохідний патрульний катер «Лань», $\mathrm{A}_{5}$ - ракетний катер «Веспа», $\mathrm{A}_{6}$ - багатоцільовий корвет «Гайдук», $\mathrm{A}_{7}$ - малий корвет «Каракал». 3 огляду на проведений аналіз визначено пріоритети (типи катерів і кораблів), що вказують на домінування альтернатив: $\mathrm{A}_{5}$ - ракетний катер «Веспа», $\mathrm{A}_{6}$ й $\mathrm{A}_{7}$ - корвети «Гайдук» $\mathrm{i}$ «Каракал». Отже, доходимо висновку, що відроджуваний флот повинен мати у своєму складі як катери, так і корвети, що забезпечить найбільш ефективне вирішення завдань обороноздатності морських кордонів.

Наукова новизна отриманих результатів полягає в тому, що вперше для вирішення завдання подальшого розвитку ВМС України використано підхід на основі ФОРСАЙТ-технологій. Практична значущість таких результатів полягає в тому, що запропонований підхід може бути використаний для вирішення завдань оборонного будівництва в умовах наявних слабо структурованих проблем та невизначеностей.

Ключові слова: ФОРСАЙТ-технології; метод аналізу ієрархій; вибір складу ВМС України; моделювання сценарію; критерій; альтернатива.

\section{ПОСТАНОВКА ЗАДАЧІ}

Однією 3 найважливіших функцій діяльності будь-якої держави є зміцнення військової безпеки, яка визначається станом обороноздатності країни та іiі можливістю забезпечити захист національних інтересів засобами збройної боротьби і звести до мінімуму шкоду та руйнівні наслідки. 3 огляду на це оборонне будівництво $є$ важливим компонентом військової безпеки і визначається цілою низкою факторів: матеріально-фінансовими можливостями забезпечення військового будівництва; станом військово-промислового комплексу (далі - ВПК); обсягом фінансування вкладених коштів в оборону; науково-технічним потенціалом, що дозволяє створювати нові види озброєнь; кількісними та якісними параметрами Збройних сил тощо. Водночас сучасний світовий розвиток характеризується динамічністю таких важливих процесів, як: глобалізація економіки, зменшення природних запасів, боротьбаза енергетичні ринки, погіршення екологічного та кліматичного стану планети, загострення міжнаціональних відносин, наявність низки країн, які проводять агресивну політику, тощо. Досить часто такі процеси не $є$ монотонними, їм властиві стрибкоподібні зміни.

Зазначені процеси своєю чергою впливають на перелічені фактори оборонного будівництва, що проявляється в наявності різних невизначеностей і ризиків. Це ускладнює вирішення завдань планування і прогнозування з використанням так званих методів «кількісного прогнозування» (forecast). Тому в сучасних умовах актуальним стає нове завдання - репрезентувати майбутне, яке не можна інтерпретувати як звичайне продовження минулого, у зв'язку з тим, що було відомо в минулому [1-3]. Таке питання отримало назву передбачення (від англ. «foresight» - «погляд у майбутнє»).

\section{АНАЛІЗ ОСТАННІХ ДОСЛІДЖЕНЬ І ПУБЛІКАЦІЙ}

До теперішнього часу ФОРСАЙТ-технології формувались як самостійне науково-практичне спрямування [4-6], принциповою відмінністю якого від колишньої практики вирішення завдань прогнозування $\epsilon$ те, що використовуються методи, котрі мають не кількісний, а якісний характер. За даними Організації Об'єднаних Націй з технологічного розвитку (ЮНІДО), головного координатора цих робіт, національні програми 3 технологічного передбачення сьогодні запровадили понад 40 країн світу. Слід зазначити, що кількість публікацій, присвячених питанням застосування ФОРСАЙТ-технологій $[5 ; 7 ; 8]$, зокрема, і в оборонній сфері, невелика, ї зміст обмежений переважно загальним описом можливостей таких технологій, без детального розгляду конкретних прикладів. 


\section{МЕТА ДОСЛІДЖЕННЯ}

Метою статті $\epsilon$ аналіз використання ФОРСАЙТтехнологій для вирішення завдань вибору складу ВMC України із застосуванням методу аналізу ієрархій.

\section{МЕТОДИ, ОБ'ЄКТ}

\section{ТА ПРЕДМЕТ ДОСЛІДЖЕННЯ}

Об'єктом дослідження є ФОРСАЙТ-орієнтована методологія для вибору складу ВМС України. Предметом дослідження став корабельний склад ВМС України.

ФОРСАЙТ-технологія використовується як системний інструмент вибору пріоритетів у різних сферах людської діяльності, в межах якого робляться спроби побудови образу майбутнього в середньо- і довгостроковій перспективі, спрямований на підвищення якості прийнятих рішень та координацію спільних дій $[1 ; 6]$. ФОРСАЙТ-технологія - це система методів отримання та аналізу експертних оцінок стратегічних напрямів соціально-економічного та інноваційного розвитку, виявлення критичних технологій, здатних забезпечити «прорив» у різних сферах розвитку суспільства.

Виокремлюють три етапи розвитку ФОРСАЙTA [9]: перший етап - технологічний ФОРСАЙТ (Technology Foresight), використовується для розробки перспектив науково-технічної сфери; другий етап - ринково-орієнтований ФОРСАЙТ; третій етап соціально-економічний ФОРСАЙТ, що застосовується для різних соціально-економічних цілей. Серед основних методів проведення ФОРСАЙТА виділяють такі [10]: метод Дельфі, мозковий штурм, експертні панелі, технологічні дорожні карти, сценування, багатокритеріальний аналіз, ігрове та імітаційне моделювання тощо.

Загалом ФОРСАЙТ-дослідження можуть бути проведені в чотири етапи за схемою [10], представленою на рис. 1.

При цьому побудова сценаріїв та їх багатокритеріальний аналіз розглядаються як методологічна основа передбачення [1]. Метод сценаріїв - це інструмент декомпозиції завдань передбачення, що має на меті виокремлення деяких варіантів розвитку подій (тобто сценаріїв), які в сукупності охоплюють всі можливі варіанти розвитку. При цьому кожен окремий сценарій повинен допускати можливість досить точного передбачення, а загальна кількість сценаріїв має бути осяжною. Як інструментальні засоби для побудови і графічного відображення сценаріїв широко використовуються графи типу «дерево»: дерево цілей, дерево подій, дерево рішень, ієрархічні структури тощо.

Серед методів багатокритеріального аналізу сценаріїв найбільше застосування в ФОРСАЙТ-технологіях отримали метод аналізу ієрархій (далі - MAI) і метод

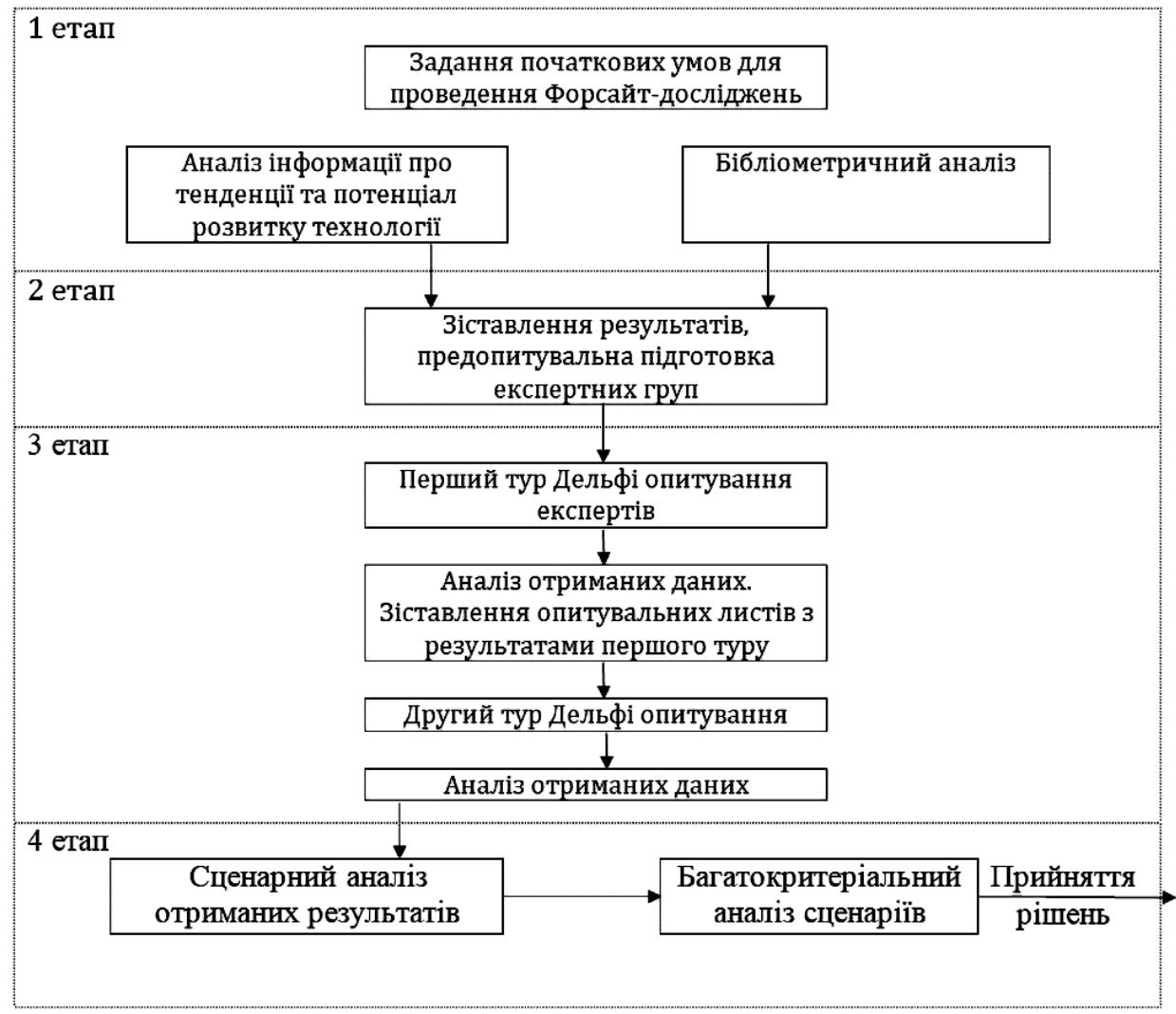

Рис. 1. Схема проведення ФОРСАЙТ-досліджень 


\section{КОМП'ЮТЕРНІ НАУКИ ТА ІНФОРМАЦІЙНІ ТЕХНОЛОГІЇ № 3-2021}

аналітичних мереж, розроблені Т. Сааті [11-13]. МАI $\epsilon$ процедурою для ієрархічного уявлення елементів, що визначають суть будь-якої проблеми. Метод полягає в декомпозиції проблеми на більш прості складники і відображається у вигляді ієрархічних структур із різною кількістю рівнів ієрархії з подальшим використанням попарного порівняння критеріїв та альтернатив (варіантів рішень) щодо кожного з критеріїв. Таке порівняння видається у формі зворотно-симетричних матриць, за елементами яких визначається вектор власних значень 3 наступним їх нормуванням і підрахунком вагових коефіцієнтів. Такі коефіцієнти характеризують набір локальних пріоритетів, з яких особі, що приймає рішення, необхідно зробити свій вибір. Формалізуємо викладене в такому вигляді:

$$
\begin{aligned}
& B=\left(\begin{array}{cccc}
b_{11} & b_{12} & \ldots & b_{1 n} \\
b_{21} & b_{22} & \ldots & b_{2 n} \\
\ldots & & \\
b_{n 1} & b_{n 2} & \cdots & b_{n n}
\end{array}\right) \Rightarrow \\
& \Rightarrow\left\{\begin{array}{c}
\sqrt[n]{b_{11} * b_{12} * \ldots * b_{1 n}}=d_{1} \\
\sqrt[n]{b_{21} * b_{22} * \ldots * b_{2 n}}=d_{2} \\
\ldots \\
\sqrt[n]{b_{n 1} * b_{n 2} * \ldots * b_{n n}}=d_{n}
\end{array}\right\} \Rightarrow \\
& \Rightarrow\left(d_{1}+d_{2}+\cdots+d_{n}\right)=D \Rightarrow \\
& \Rightarrow\left\{\frac{d_{1}}{D}=\omega_{1}, \frac{d_{2}}{D}=\omega_{2}, \ldots, \frac{d_{n}}{D}=\omega_{n}\right\} \Rightarrow
\end{aligned}
$$

$\Rightarrow\left(\omega_{1}, \omega_{2}, \ldots, \omega_{n}\right)-$ вектор пріоритетів.

Тут $B$ - зворотно-симетрична матриця попарних порівнянь елементів $b_{\mathrm{ij}} ; d_{\mathrm{i}}-$ власний вектор; $D$ - оператор нормування; $\omega_{\mathrm{i}}-$ вагові коефіцієнти пріоритетів. Порівняння виконуються 3 використанням фундаментальної шкали (табл. 1).

Таблиця 1. Фундаментальна шкала

\begin{tabular}{|c|l|l|}
\hline $\begin{array}{c}\text { Ступінь } \\
\text { переваги }\end{array}$ & \multicolumn{1}{|c|}{ Визначення } & \multicolumn{1}{|c|}{ Коментар } \\
\hline 1 & \multicolumn{1}{|c|}{3} \\
\hline 1 & Рівна перевага & $\begin{array}{l}\text { Дві альтернативи, однакові } \\
\text { з позиції мети }\end{array}$ \\
\hline 2 & $\begin{array}{l}\text { Слабкий ступінь } \\
\text { переваги }\end{array}$ & $\begin{array}{l}\text { Проміжна градація між } \\
\text { рівною і середньою пере- } \\
\text { вагами }\end{array}$ \\
\hline 3 & $\begin{array}{l}\text { Середній } \\
\text { ступінь } \\
\text { переваги }\end{array}$ & $\begin{array}{l}\text { Досвід експерта дозволяє } \\
\text { вважати одну з альтернатив } \\
\text { трохи кращою за іншу }\end{array}$ \\
\hline 4 & $\begin{array}{l}\text { Перевага вище } \\
\text { середього }\end{array}$ & $\begin{array}{l}\text { Проміжна градація між се- } \\
\text { редньою і помірно сильною } \\
\text { перевагами }\end{array}$ \\
\hline 5 & $\begin{array}{l}\text { Помірно сильна } \\
\text { перевага }\end{array}$ & $\begin{array}{l}\text { Досвід експерта дозволяє } \\
\text { вважати одну з альтернатив } \\
\text { явно кращою за іншу }\end{array}$ \\
\hline 6 & Сильна перевага & $\begin{array}{l}\text { Проміжна градація між } \\
\text { помірно сильною і дуже } \\
\text { сильною перевагами }\end{array}$ \\
\hline
\end{tabular}

Продовження таблиці 1

\begin{tabular}{|c|l|l|}
\hline 1 & \multicolumn{1}{|c|}{2} & \multicolumn{1}{c|}{3} \\
\hline 7 & $\begin{array}{l}\text { Дуже сильна } \\
\text { (очевидна) пере- } \\
\text { вага }\end{array}$ & $\begin{array}{l}\text { Досвід експерта дозволяє } \\
\text { вважати, що одна 3 альтер- } \\
\text { натив домінує над іншою }\end{array}$ \\
\hline 8 & $\begin{array}{l}\text { Дуже-дуже } \\
\text { сильна перевага }\end{array}$ & $\begin{array}{l}\text { Проміжна градація між } \\
\text { дуже сильною й абсолют- } \\
\text { ною перевагами }\end{array}$ \\
\hline 9 & $\begin{array}{l}\text { Абсолютна } \\
\text { перевага }\end{array}$ & $\begin{array}{l}\text { Очевидність переваги } \\
\text { однієї альтернативи над } \\
\text { іншою має незаперечне } \\
\text { підтвердження }\end{array}$ \\
\hline
\end{tabular}

Джерело: складено авторами на основі [11, 13]

Далі виконується перевірка узгодженості елементів матриці $\mathrm{B}$ за допомогою підрахунку відношення узгодженості (ВУ):

$\mathrm{BУ}=\mathrm{IV} / \mathrm{BI}$, де IУ $=\left(\lambda_{\max }-n\right) /(n-1)-$ індекс узгодженості.

$$
\begin{gathered}
\lambda_{\max }=\left(\sum_{j=1}^{n_{1}} b_{j}\right) * \omega_{1}+\left(\sum_{j=1}^{n_{2}} b_{j}\right) * \omega_{2}+\cdots+ \\
+\left(\sum_{j=1}^{n_{n}} b_{j}\right) * \omega_{n},
\end{gathered}
$$

де $\lambda_{\max }-$ максимальне власне число; $n-$ кількість порівнюваних елементів; ВІ - випадковий індекс (призначається згідно з табл. 2). Для $n=3 \mathrm{BI}=0,52$.

Таблиця 2. Значення випадкового індексу (BI)

\begin{tabular}{|l|c|c|c|c|c|c|c|c|c|c|}
\hline $\begin{array}{l}\text { Порядок } \\
\text { матриці } \\
\text { суджень }\end{array}$ & 1 & 2 & 3 & 4 & 5 & 6 & 7 & 8 & 9 & 10 \\
\hline $\begin{array}{l}\text { Випадковий } \\
\text { індекс (ВI) }\end{array}$ & 0 & 0 & 0,52 & 0,89 & 1,1 & 1,2 & 1,3 & 1,4 & 1,4 & 1,4 \\
\hline
\end{tabular}

Джерело: складено авторами на основі $[11,13]$

Обрахований власний вектор прийнятний у тому випадку, якщо ОС $\leq 0,10$ (може допускатися 0,2, але не більше). Для матриць порядку $\mathrm{n}=3$ бажано виконання $\mathrm{OC} \leq 0,05$, для $\mathrm{n}=4-\mathrm{OC} \leq 0,08$. Якщо відношення узгодженості (ВУ) перевищує 0,10 , то необхідно глибше вивчити проблему і переглянути судження відповідно до фундаментальної шкали (див. табл. 1).

\section{ОСНОВНИЙ МАТЕРІАЛ}

Визначальним документом, що містить дорожню карту будівництва Військово-морських сил України 3 урахуванням фінансових можливостей держави і потреб національної оборони, є «Стратегія Військовоморських сил Збройних сил України-2035» [14]. Вона передбачає три етапи. Завданням 1-го етапу (до 2025 р.) є забезпечення гарантованого захисту національних інтересів у межах 12-мильної прибережної зони; на 2-му етапі (до 2030 р.) зона відповідальності пошириться на 200-мильну виключно економічну зону; третій етап передбачає дії флоту за межами Чорного моря. Для реалізації 1-го етапу необхідно буде близько 100 млн доларів на рік, 
другий - зажадає вкладень від 150 до 200 млн доларів на рік, а третій етап коштуватиме бюджету України від 200 до 400 млн доларів щорічно.

На 1-му етапі стратегії передбачається створення так званого «москітного» флоту, що складається 3 порівняно невеликих катерів. До позитивних характеристик такого флоту можна віднести маневреність, швидкість, малопомітність, низьку вартість обслуговування i ремонту, невелику та дешеву портову інфраструктуру тощо. Водночас серед його недоліків визначають невисоку автономність плавання (5-7 днів), через що катери здатні діяти тільки в межах невеликої прибережної зони; низьке мореплавство (до 4 балів хвилювання моря), можливість використання зброї до 2-х балів хвилювання моря; слабке або взагалі відсутнє протиповітряне і протикорабельне (для ураження великих кораблів) озброєння тощо [15-16].

Ці обставини відображені у двох концепціях відродження флоту:

Перша означає флот, що складається з великої кількості малих бойових кораблів, які здатні атакувати більші кораблі, будучи менш уразливими завдяки малому розміру, швидкості, маневреності та їх великій кількості;

Друга передбачає «класичний флот» із фрегатами i корветами, який допускає існування «москітного флоту» як свого складника.

Обидві концепції мають як прихильників, так i противників серед фахівців із будівництва та експлуатації кораблів флоту.

До основних завдань, що виконуються ВМС України, належать: патрулювання в ближній морській зоні; захист важливих об'єктів морської інфраструктури та прибережної зони; протидія ймовірній висадці десантних засобів противника на узбережжя тощо [15-16]. Враховуючи зазначене, розглянемо основні характеристики катерів і кораблів, що наразі будуються та проєктуються. До малих патрульних катерів, що будуються й приймаються до складу ВМСУ, відносяться «Гюрза» і «Кентавр»:

1. Річковий броньований катер «Гюрза» має такі характеристики: довжина - 20,34 м; ширина - 4,86 м; осадка - 0,86 м; водотоннажність - 36,4 т; швидкість 28 вуз.; озброєння - 30 мм АУ, ПУ ПТРК, кулемети; автономність - 5 діб; орієнтовна вартість - 5,4 млн доларів (із розрахунку, що одна тонна металу корабля коштує 0,15 млн доларів).

Досвід експлуатації перших моделей «Гюрзи» показав недостатнє його мореплавство (невелика водотоннажність дає можливість виходу в море за хвиль до 4 балів), катер може використовувати озброєння за хвилювання моря до 2 балів, відсутність протикорабельного і протиавіаційного озброєння дозволяє воювати йому тільки з катерами подібного типу.
2. Десантно-штурмовий катер «Кентавр» характеризується такими показниками: довжина - 24,3 м; ширина - 4,8 м; осадка - 1,0 м; водотоннажність - 47 т; швидкість - не менше 35 вуз.; озброєння - дві пускові установки 80 мм РСЗВ, два модулі кулеметів калібру 12,7 мм, 40 мм гранатомет, кілька одиниць ПЗРК «Игла»; десант-місткість - до 36 осіб; автономність до 5 діб; орієнтовна вартість - 7 млн доларів.

Дослідні випробування катера показали невідповідність максимально заявленій швидкості, наявність певного крену, можливість виходу в море за хвиль не більше 3 балів.

3. Очевидно, до малих патрульних катерів можна віднести і передані США ВМС України катери типу «Island». Два таких катери - «Слов'янськ» i «Старобільськ» - стали у стрій, ще 3 готуються до передачі.

Основні характеристики катерів: водотоннажність - 165 т; довжина - 33,5 м; швидкість - 30 вуз.; автономність - 5 діб; озброєння: одна 25 мм автоматична АУ, два 12,7 мм кулемети. Катери вимагають доозброєння, зокрема, планується установка 30 мм АУ, 30 мм автоматичного гранатомета, двох ПТРК «Бар'єр».

До великих патрульних катерів, якими планують оснастити ВМС України, належать «Лань» і «Веспа»:

4. Швидкохідний патрульний катер «Лань» має такі характеристики: довжина - 54,2 м; ширина - 9,3 м; осадка - 2,5 м; водотоннажність - 440 т; швидкість - не менше 34 вуз.; автономність - 15 діб; озброєння - одна 76 мм АУ, одна 30 мм АУ, кулемети калібру 12,7 мм; орієнтовна вартість - 65 млн доларів. Вимагає доозброєння (імовірно, протикорабельними ракетами «Нептун»).

5. Ракетний катер «Веспа» - це модернізована «Лань», має такі характеристики: довжина - 64,6 м; ширина - 9,6 м; осадка - 3,65 м; максимальна швидкість - до 40 вуз.; водотоннажність - 640 т; озброєння - вісім ПКР «Нептун», чотири ЗРК «Арбалет-К», шістнадцять ЗРК «Игла», одна 76 мм АУ, дві 30 мм АУ, два 12,7 мм кулемети; автономність - не менше 15 діб; орієнтовна вартість - 96 млн доларів.

Обидва катери повинні стати основою ударного потенціалу ВМС до введення в дію корвета «Володимир Великий» (закладений у 2011 р).

3 метою озброєння українського флоту корветами розглядаються багатоцільовий корвет «Гайдук» і малий корвет «Каракал». Ці кораблі призначені для дій у закритих морях і прибережних районах відкритих морів, для боротьби 3 надводними кораблями і підводними човнами, бойової охорони районів базування сил флоту, формування десантних загонів і конвоїв, охорони конвоїв цивільних суден або десантних засобів під час переходу морем, ведення радіоелектронної розвідки, боротьби з піратством. У мирний час кораблі можуть залучатися 


\section{КОМП'ЮТЕРНІ НАУКИ ТА ІНФОРМАЦІЙНІ ТЕХНОЛОГІЇ № 3-2021}

до патрулювання в морській виключно економічній зоні, до охорони держкордону і боротьби з контрабандою. Зброя застосовується на всіх досяжних швидкостях за хвилювання моря до 5 балів включно, корвети оснащені заспокоювачами хитавиці. Орієнтовна вартість головного корвета - 125 млн доларів, серійного корабля (5-го в серії) - 110 млн доларів.

6. Багатоцільовий корвет «Гайдук» має такі характеристики: довжина - 85,47 м; ширина - 10,15 м; осадка - 3,1 м; водотоннажність - 1200 т; швидкість 30 вуз.; автономність - понад 15 діб; озброєння: одна 100 мм АУ, 2 х 4 ПКР «Уран-Е», три КБР «КАШТАН» (32 ракети), 1 х 630 мм АУ, 2 х 2324 мм торпедні апарати, чотири установки пасивних перешкод, мінне озброєння, 2 х 1 12,7 мм кулемети, ВВП для вертольота типу LYNX.

7. Основні характеристики малого корвета «Каракал»: довжина - 59,8 м; ширина - 9,2 м; осадка 2,6 м; водотоннажність - 520 т; швидкість - 26 вуз; автономність - 15 діб; озброєння: 2 х 2 ПКР, ЗРК ближнього рубежу, 57-76 мм АУ; 30-35 мм АУ; орієнтовна вартість - 78 млн доларів.

Основні характеристики перелічених корветів і кораблів зведені в табл. 3 .

Для якісного моделювання сценаріїв формування корабельного складу ВМСУ скористаємося методикою:

BOCR $=\frac{\text { Benefits } * \text { Opportunities }}{\text { Costs } * \text { Risks }}=\frac{\text { Вигоди } * \text { Можливості }}{\text { Витрати } * \text { Ризики }}$

в основі якої лежить широковідомий метод аналізу ієрархій. Із цією метою побудуємо 4 трирівневі ієрархії (за кількістю таких факторів, як ВИГОДИ, МОЖЛИВОСТІ, ВИТРАТИ, РИЗИКИ), представлені на рис. 2 (а, б, в, г), та сформуємо альтернативи і критерії. Альтернативами (А) виступають розглянуті типи катерів і кораблів: $\mathrm{A}_{1}-$ «Гюрза», $\mathrm{A}_{2}-$ «Кентавр», $\mathrm{A}_{3}-$ «Island», $\mathrm{A}_{4}-$ «Лань», $\mathrm{A}_{5}-$ «Веспа», $\mathrm{A}_{6}-$ «Гайдук», $\mathrm{A}_{7}-$ «Каракал».

Показник ВИГОДИ характеризується критеріями (К), які забезпечують захист морських рубежів країни:

$K_{1}$ - гарантований захист національних інтересів у межах 12-мильної прибережної зони;

$K_{2}$ - контроль і захист 200-мильної економічної зони країни;

$\mathrm{K}_{3}$ - захист об'єктів морської інфраструктури.

Показник МОЖЛИВОСТІ характеризується такими критеріями:

$\mathrm{K}_{4}$ - боротьба 3 надводними і підводними кораблями противника;

$\mathrm{K}_{5}$ - боротьба з авіацією противника;

$\mathrm{K}_{6}$ - протидія висадці десантів противника;

$\mathrm{K}_{7}$ - формування десантних загонів і забезпечення їх висадки;

$\mathrm{K}_{8}$ - охорона конвоїв цивільних суден під час переходу морем;

$\mathrm{K}_{9}$ - боротьба з контрабандою та піратством;

$\mathrm{K}_{10}$ - ведення радіоелектронної розвідки.

Показник ВИТРАТИ представлений критеріями:

$\mathrm{K}_{11}$ - витрати на будівництво та модернізацію катерів і кораблів;

$\mathrm{K}_{12}$ - витрати на будівництво нових і розвиток наявних об'єктів морської інфраструктури;

$\mathrm{K}_{13}$ - експлуатаційні витрати на забезпечення та утримання флоту.

Таблиця 3. Основні характеристики катерів і кораблів ВМСУ

\begin{tabular}{|c|c|c|c|c|c|c|c|c|c|c|c|c|}
\hline $\begin{array}{c}\text { Найменування ка- } \\
\text { терів і кораблів }\end{array}$ & 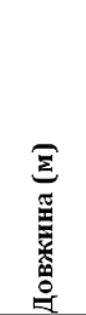 & $\begin{array}{l}\underset{\mathbf{z}}{\mathbf{z}} \\
\mathbf{3} \\
\mathbf{3}\end{array}$ & $\begin{array}{l}\underset{\pi}{\Sigma} \\
\mathbb{Z} \\
\mathbb{J} \\
0 \\
0\end{array}$ & 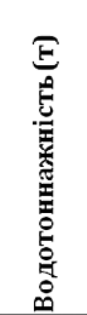 & 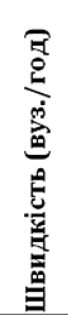 & 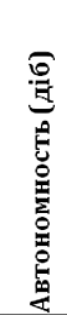 & 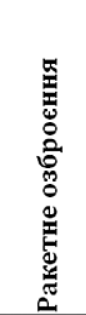 & 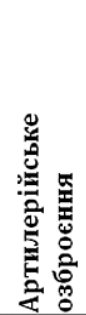 & 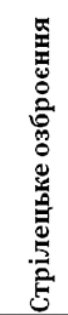 & 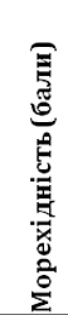 & 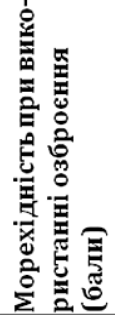 & 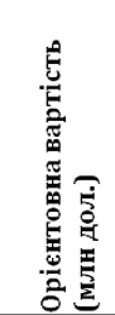 \\
\hline $\begin{array}{l}\text { Броньований катер } \\
\text { «Гюрза» }\end{array}$ & 20,34 & 4,86 & 0,86 & 36,4 & 28,0 & 5,0 & ПТРК & + & + & $\begin{array}{l}\text { до } \\
4,0 \\
\end{array}$ & до 2,0 & 5,4 \\
\hline $\begin{array}{l}\text { Десантно- } \\
\text { штурмової катер } \\
\text { «ентавр» }\end{array}$ & 24,3 & 4,8 & 1,0 & 47,0 & 35,0 & 5,0 & $\begin{array}{l}\text { РСЗО } \\
\text { ПЗРК }\end{array}$ & - & + & $\begin{array}{l}\text { до } \\
3,0\end{array}$ & - & 7,0 \\
\hline $\begin{array}{l}\text { Патрульний катер } \\
\text { «Island» }\end{array}$ & 33,5 & - & - & 165,0 & 30,0 & 5,0 & - & + & + & - & - & - \\
\hline $\begin{array}{l}\text { Патрульний катер } \\
\text { «Лань» }\end{array}$ & 54,2 & 9,3 & 2,5 & 440,0 & 34,0 & 15,0 & - & + & + & - & - & 65,0 \\
\hline $\begin{array}{l}\text { Ракетний катер } \\
\text { «Веспа» }\end{array}$ & 64,6 & 9,6 & 3,65 & 640 & 40,0 & 15,0 & $\begin{array}{l}\text { ПКР } \\
\text { ЗРК }\end{array}$ & + & + & - & - & 96,0 \\
\hline Корвет «Гайдук» & 85,5 & 10,15 & 3,1 & 1200 & 30,0 & 15,0 & $\begin{array}{l}\text { ПКР } \\
\text { ЗКБР }\end{array}$ & + & + & $\begin{array}{l}\text { до } \\
5,0\end{array}$ & - & $125-110$ \\
\hline $\begin{array}{l}\text { Малий корвет «Ка- } \\
\text { ракал» }\end{array}$ & 59,8 & 9,2 & 2,6 & 520 & 26,0 & 15,0 & $\begin{array}{l}\text { ПКР } \\
\text { ЗРК }\end{array}$ & + & + & - & - & 78,0 \\
\hline
\end{tabular}


Показник РИЗИКИ може бути визначений критеріями фінансового, проєктно-технічного й експлуатаційного характеру:

$\mathrm{K}_{14}$ - недостатність і неритмічність фінансування будівництва та модернізації кораблів і катерів;

$\mathrm{K}_{15}$ - невідповідність заявлених проєктних характеристик експлуатаційним результатам;

$\kappa_{16}-$ недоозброєння катерів і кораблів сучасним точним військовим спорядженням;

$\mathrm{K}_{17}$ - мореплавні якості катерів і кораблів;

$\mathrm{K}_{18}-$ автономність плавання.

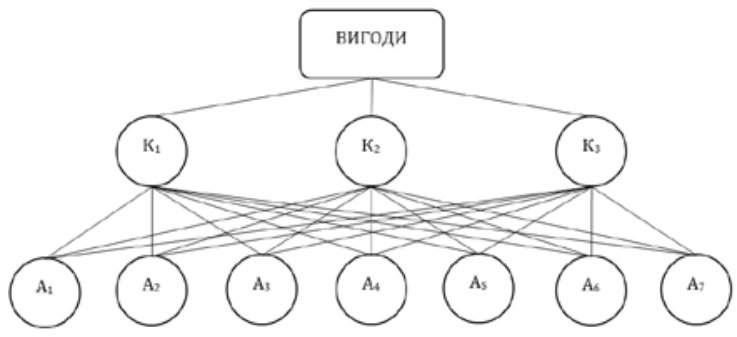

a)

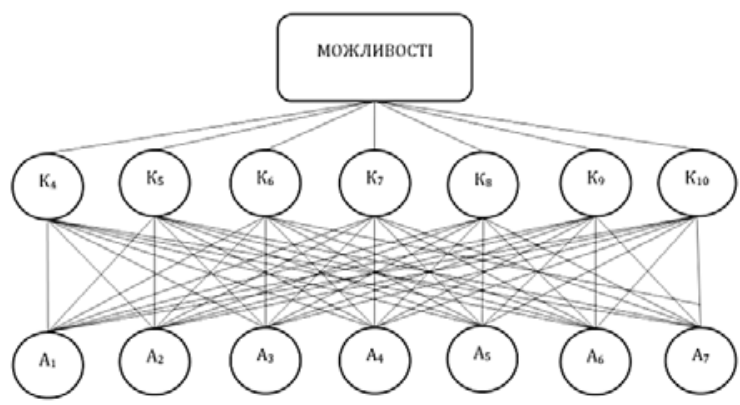

б)

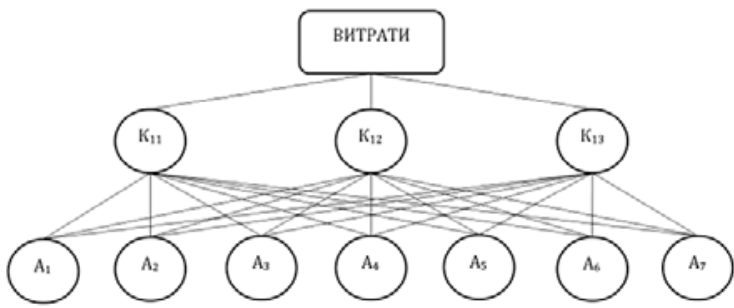

B)

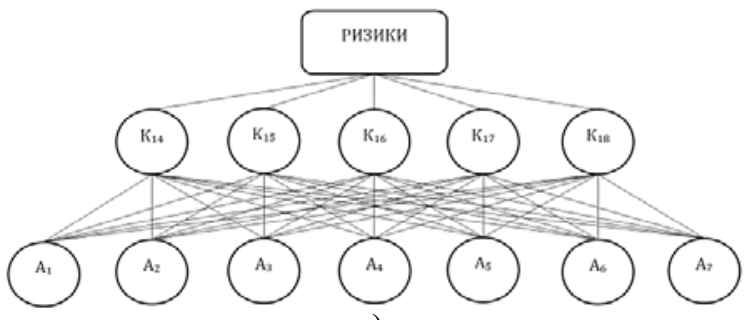

г)

Рис. 2. Ієрархії для аналізу факторів BOCR

В результаті попарного порівняння критеріїв та альтернатив щодо кожного з критеріїв за всіма чотирма факторами можуть бути отримані вагові коефіцієнти пріоритетів (табл. 4-10).
Таблиця 4. Попарне порівняння критеріїв для фактору ВИГОДИ

\begin{tabular}{|c|c|c|c|c|}
\hline Критерії & $\mathbf{K}_{\mathbf{1}}$ & $\mathbf{K}_{\mathbf{2}}$ & $\mathbf{K}_{\mathbf{3}}$ & Ваги пріоритетів \\
\hline $\mathbf{K}_{\mathbf{1}}$ & 1 & $1 / 3$ & $1 / 5$ & 0,03 \\
\hline $\mathbf{K}_{\mathbf{2}}$ & 3 & 1 & $1 / 3$ & 0,29 \\
\hline $\mathbf{K}_{\mathbf{3}}$ & 5 & 3 & 1 & 0,68 \\
\hline
\end{tabular}

Таблиця 5. Вагові коефіцієнти пріоритетів для фактору ВИГОДИ

\begin{tabular}{|c|c|c|c|c|c|}
\hline $\mathbf{K}_{\mathbf{1}}$ & $\begin{array}{c}\text { Ваги } \\
\text { пріоритетів }\end{array}$ & $\mathbf{K}_{\mathbf{2}}$ & $\begin{array}{c}\text { Ваги } \\
\text { пріоритетів }\end{array}$ & $\mathbf{K}_{\mathbf{3}}$ & $\begin{array}{c}\text { Ваги } \\
\text { пріоритетів }\end{array}$ \\
\hline $\mathbf{A}_{\mathbf{1}}$ & 0,05 & $\mathbf{A}_{\mathbf{1}}$ & 0,01 & $\mathbf{A}_{\mathbf{1}}$ & 0,05 \\
\hline $\mathbf{A}_{\mathbf{2}}$ & 0,05 & $\mathbf{A}_{\mathbf{2}}$ & 0,01 & $\mathbf{A}_{\mathbf{2}}$ & 0,05 \\
\hline $\mathbf{A}_{\mathbf{3}}$ & 0,05 & $\mathbf{A}_{\mathbf{3}}$ & 0,01 & $\mathbf{A}_{\mathbf{3}}$ & 0,01 \\
\hline $\mathbf{A}_{\mathbf{4}}$ & 0,1 & $\mathbf{A}_{\mathbf{4}}$ & 0,05 & $\mathbf{A}_{\mathbf{4}}$ & 0,1 \\
\hline $\mathbf{A}_{\mathbf{5}}$ & 0,3 & $\mathbf{A}_{\mathbf{5}}$ & 0,35 & $\mathbf{A}_{\mathbf{5}}$ & 0,25 \\
\hline $\mathbf{A}_{\mathbf{6}}$ & 0,25 & $\mathbf{A}_{\mathbf{6}}$ & 0,30 & $\mathbf{A}_{\mathbf{6}}$ & 0,3 \\
\hline $\mathbf{A}_{\mathbf{7}}$ & 0,15 & $\mathbf{A}_{\mathbf{7}}$ & 0,27 & $\mathbf{A}_{\mathbf{7}}$ & 0,24 \\
\hline
\end{tabular}

Визначимо пріоритети альтернатив (типів катерів і кораблів) щодо обраних критеріїв фактору ВИГОДИ:

$\left[\begin{array}{ccc}0,05 & 0,01 & 0,05 \\ 0,05 & 0,01 & 0,05 \\ 0,05 & 0,01 & 0,01 \\ 0,10 & 0,05 & 0,1 \\ 0,30 & 0,35 & 0,25 \\ 0,25 & 0,30 & 0,3 \\ 0,15 & 0,27 & 0,24\end{array}\right] \times\left[\begin{array}{c}0,03 \\ 0,29 \\ 0,68\end{array}\right]=\left[\begin{array}{c}0,04 \\ 0,038 \\ 0,011 \\ 0,085 \\ 0,28 \\ 0,30 \\ 0,25\end{array}\right] \begin{gathered}A_{1} \\ A_{2} \\ A_{3} \\ A_{4} \\ A_{5} \\ A_{7}\end{gathered}$

Таблиця 6. Вагові коефіцієнти пріоритетів для фактору МОЖЛИВОСТІ

\begin{tabular}{|c|c|c|c|c|c|}
\hline $\mathbf{K}_{4}$ & $\begin{array}{c}\text { Ваги } \\
\text { пріоритетів }\end{array}$ & $\mathbf{K}_{5}$ & $\begin{array}{c}\text { Ваги } \\
\text { пріоритетів }\end{array}$ & $\mathbf{K}_{6}$ & $\begin{array}{c}\text { Ваги } \\
\text { пріоритетів }\end{array}$ \\
\hline $\mathbf{A}_{1}$ & 0,01 & $\mathbf{A}_{1}$ & 0,01 & $\mathbf{A}_{1}$ & 0,05 \\
\hline $\mathbf{A}_{2}$ & 0,01 & $\mathbf{A}_{2}$ & 0,05 & $\mathrm{~A}_{2}$ & 0,1 \\
\hline $\mathbf{A}_{3}$ & 0,01 & $\mathbf{A}_{3}$ & 0,1 & $\mathbf{A}_{3}$ & 0,1 \\
\hline $\mathbf{A}_{4}$ & 0,1 & $\mathbf{A}_{4}$ & 0,1 & $\mathbf{A}_{4}$ & 0,15 \\
\hline $\mathbf{A}_{5}$ & 0,27 & $\mathbf{A}_{5}$ & 0,26 & $A_{5}$ & 0,2 \\
\hline $\mathbf{A}_{6}$ & 0,35 & $A_{6}$ & 0,25 & $\mathbf{A}_{6}$ & 0,2 \\
\hline $\mathbf{A}_{7}$ & 0,25 & $\mathbf{A}_{7}$ & 0,23 & $\mathbf{A}_{7}$ & 0,2 \\
\hline $\mathbf{K}_{7}$ & $\begin{array}{c}\text { Ваги } \\
\text { пріоритетів }\end{array}$ & $\mathbf{K}_{8}$ & $\begin{array}{c}\text { Ваги } \\
\text { пріоритетів }\end{array}$ & $\mathbf{K}_{\mathbf{9}}$ & $\begin{array}{c}\text { Ваги } \\
\text { пріоритетів }\end{array}$ \\
\hline $\mathbf{A}_{1}$ & 0,01 & $\mathbf{A}_{1}$ & 0,1 & $A_{1}$ & 0,1 \\
\hline $\mathbf{A}_{2}$ & 0,25 & $\mathbf{A}_{2}$ & 0,15 & $A_{2}$ & 0,1 \\
\hline $\mathbf{A}_{3}$ & 0,05 & $\mathbf{A}_{3}$ & 0,1 & $A_{3}$ & 0,1 \\
\hline $\mathbf{A}_{4}$ & 0,15 & $\mathbf{A}_{4}$ & 0,2 & $\mathbf{A}_{4}$ & 0,15 \\
\hline $\mathbf{A}_{5}$ & 0,22 & $\mathbf{A}_{5}$ & 0,15 & $A_{5}$ & 0,2 \\
\hline$A_{6}$ & 0,18 & $A_{6}$ & 0,16 & $A_{6}$ & 0,18 \\
\hline $\mathbf{A}_{7}$ & 0,14 & $\mathbf{A}_{7}$ & 0,14 & $\mathbf{A}_{7}$ & 0,17 \\
\hline$K_{10}$ & $\begin{array}{c}\text { Ваги } \\
\text { пріоритетів }\end{array}$ & & & & \\
\hline $\mathbf{A}_{1}$ & 0,05 & & & & \\
\hline $\mathbf{A}_{2}$ & 0,05 & & & & \\
\hline $\mathbf{A}_{3}$ & 0,1 & & & & \\
\hline $\mathbf{A}_{4}$ & 0,2 & & & & \\
\hline $\mathbf{A}_{5}$ & 0,18 & & & & \\
\hline $\mathbf{A}_{6}$ & 0,3 & & & & \\
\hline $\mathbf{A}_{7}$ & 0,12 & & & & \\
\hline
\end{tabular}




\section{КОМП'ЮТЕРНІ НАУКИ ТА ІНФОРМАЦІЙНІ ТЕХНОЛОГІЇ № 3- 2021}

Пріоритети альтернатив щодо фактору МОЖЛИВОСТІ мають таке значення:

$\left[\begin{array}{ccccccc}0,01 & 0,01 & 0,05 & 0,01 & 0,1 & 0,1 & 0,05 \\ 0,01 & 0,05 & 0,1 & 0,25 & 0,15 & 0,1 & 0,05 \\ 0,01 & 0,1 & 0,1 & 0,05 & 0,10 & 0,1 & 0,10 \\ 0,10 & 0,1 & 0,15 & 0,15 & 0,20 & 0,15 & 0,20 \\ 0,27 & 0,26 & 0,20 & 0,22 & 0,15 & 0,20 & 0,18 \\ 0,35 & 0,25 & 0,20 & 0,18 & 0,16 & 0,18 & 0,30 \\ 0,25 & 0,23 & 0,20 & 0,14 & 0,14 & 0,17 & 0,12\end{array}\right] \times\left[\begin{array}{c}0,32 \\ 0,25 \\ 0,13 \\ 0,1 \\ 0,1 \\ 0,05 \\ 0,05\end{array}\right]=\left[\begin{array}{c}0,02 \\ 0,08 \\ 0,15 \\ 0,13 \\ 0,23 \\ 0,26 \\ 0,20\end{array}\right] \begin{aligned} & A_{1} \\ & A_{2} \\ & A_{3} \\ & A_{4} \\ & A_{5} \\ & A_{6}\end{aligned}$

Таблиця 7. Попарне порівняння критеріїв для фактору ВИТРАТИ

\begin{tabular}{|c|c|c|c|c|}
\hline Критерії & $\mathbf{K}_{\mathbf{1 1}}$ & $\mathbf{K}_{\mathbf{1 2}}$ & $\mathbf{K}_{\mathbf{1 3}}$ & Ваги пріоритетів \\
\hline $\mathbf{K}_{\mathbf{1 1}}$ & 1 & 5 & 3 & 0,68 \\
\hline $\mathbf{K}_{\mathbf{1 2}}$ & $1 / 5$ & 1 & $1 / 3$ & 0,03 \\
\hline $\mathbf{K}_{\mathbf{1 3}}$ & $1 / 3$ & 3 & 1 & 0,29 \\
\hline
\end{tabular}

Таблиця 8. Вагові коефіцієнти пріоритетів для фактору ВИТРАТИ

\begin{tabular}{|c|c|c|c|c|c|}
\hline $\mathbf{K}_{\mathbf{1 1}}$ & $\begin{array}{c}\text { Ваги } \\
\text { пріоритетів }\end{array}$ & $\mathbf{K}_{\mathbf{1 2}}$ & $\begin{array}{c}\text { Ваги } \\
\text { пріоритетів }\end{array}$ & $\mathbf{K}_{\mathbf{1 3}}$ & $\begin{array}{c}\text { Ваги } \\
\text { пріоритетів }\end{array}$ \\
\hline $\mathbf{A}_{\mathbf{1}}$ & 0,05 & $\mathbf{A}_{\mathbf{1}}$ & 0,01 & $\mathbf{A}_{\mathbf{1}}$ & 0,04 \\
\hline $\mathbf{A}_{\mathbf{2}}$ & 0,05 & $\mathbf{A}_{\mathbf{2}}$ & 0,01 & $\mathbf{A}_{\mathbf{2}}$ & 0,04 \\
\hline $\mathbf{A}_{\mathbf{3}}$ & 0,01 & $\mathbf{A}_{\mathbf{3}}$ & 0,01 & $\mathbf{A}_{\mathbf{3}}$ & 0,05 \\
\hline $\mathbf{A}_{\mathbf{4}}$ & 0,15 & $\mathbf{A}_{\mathbf{4}}$ & 0,05 & $\mathbf{A}_{\mathbf{4}}$ & 0,12 \\
\hline $\mathbf{A}_{\mathbf{5}}$ & 0,24 & $\mathbf{A}_{\mathbf{5}}$ & 0,3 & $\mathbf{A}_{\mathbf{5}}$ & 0,2 \\
\hline $\mathbf{A}_{\mathbf{6}}$ & 0,3 & $\mathbf{A}_{\mathbf{6}}$ & 0,36 & $\mathbf{A}_{\mathbf{6}}$ & 0,35 \\
\hline $\mathbf{A}_{\mathbf{7}}$ & 0,2 & $\mathbf{A}_{\mathbf{7}}$ & 0,3 & $\mathbf{A}_{\mathbf{7}}$ & 0,2 \\
\hline
\end{tabular}

Значення пріоритетів альтернатив щодо фактору ВИТРАТИ можуть бути отримані в такий спосіб:

$\left[\begin{array}{lll}0,05 & 0,01 & 0,04 \\ 0,05 & 0,01 & 0,04 \\ 0,01 & 0,01 & 0,05 \\ 0,15 & 0,05 & 0,12 \\ 0,24 & 0,30 & 0,20 \\ 0,30 & 0,36 & 0,35 \\ 0,20 & 0,30 & 0,20\end{array}\right] \times\left[\begin{array}{l}0,68 \\ 0,03 \\ 0,29\end{array}\right]=\left[\begin{array}{l}0,05 \\ 0,05 \\ 0,02 \\ 0,15 \\ 0,23 \\ 0,30 \\ 0,20\end{array}\right]_{A_{7}}^{A_{1}} A_{A_{3}}$

Таблиця 9. Попарне порівняння критеріїв для фактору РИЗИКИ

\begin{tabular}{|c|c|c|c|c|c|c|}
\hline Критерії & $\mathbf{K}_{\mathbf{1 4}}$ & $\mathbf{K}_{\mathbf{1 5}}$ & $\mathbf{K}_{\mathbf{1 6}}$ & $\mathbf{K}_{\mathbf{1 7}}$ & $\mathbf{K}_{\mathbf{1 8}}$ & $\begin{array}{c}\text { Ваги } \\
\text { пріоритетів }\end{array}$ \\
\hline $\mathbf{K}_{\mathbf{1 4}}$ & 1 & 6 & 5 & 2 & 2 & 0,47 \\
\hline $\mathbf{K}_{\mathbf{1 5}}$ & $1 / 6$ & 1 & $1 / 5$ & 3 & 3 & 0,1 \\
\hline $\mathbf{K}_{\mathbf{1 6}}$ & $1 / 5$ & 5 & 1 & 4 & 4 & 0,28 \\
\hline $\mathbf{K}_{\mathbf{1 7}}$ & $1 / 2$ & $1 / 3$ & $1 / 4$ & 1 & 3 & 0,086 \\
\hline $\mathbf{K}_{\mathbf{1 8}}$ & $1 / 2$ & $1 / 3$ & $1 / 4$ & $1 / 3$ & 1 & 0,054 \\
\hline
\end{tabular}

Таблиця 10. Вагові коефіцієнти пріоритетів для фактору РИЗИКИ

\begin{tabular}{|c|c|c|c|c|c|}
\hline $\mathbf{K}_{14}$ & \begin{tabular}{|c|} 
Ваги \\
пріоритетів
\end{tabular} & $\mathbf{K}_{15}$ & \begin{tabular}{|c|} 
Ваги \\
пріоритетів
\end{tabular} & $K_{16}$ & $\begin{array}{c}\text { Ваги } \\
\text { пріоритетів }\end{array}$ \\
\hline $\mathbf{A}_{1}$ & 0,05 & $\mathbf{A}_{1}$ & 0,2 & $\mathbf{A}_{1}$ & 0,2 \\
\hline $\mathbf{A}_{2}$ & 0,05 & $\mathbf{A}_{2}$ & 0,2 & $\mathbf{A}_{2}$ & 0,2 \\
\hline $\mathbf{A}_{3}$ & 0,10 & $\mathbf{A}_{3}$ & 0,05 & $\mathbf{A}_{3}$ & 0,2 \\
\hline $\mathbf{A}_{4}$ & 0,15 & $\mathbf{A}_{4}$ & 0,13 & $\mathbf{A}_{4}$ & 0,2 \\
\hline $\mathbf{A}_{5}$ & 0,35 & $\mathbf{A}_{5}$ & 0,14 & $\mathbf{A}_{5}$ & 0,05 \\
\hline $\mathbf{A}_{6}$ & 0,2 & $\mathbf{A}_{6}$ & 0,13 & $\mathbf{A}_{6}$ & 0,1 \\
\hline $\mathbf{A}_{7}$ & 0,1 & $\mathbf{A}_{7}$ & 0,15 & $\mathbf{A}_{7}$ & 0,05 \\
\hline $\mathbf{K}_{17}$ & \begin{tabular}{|c|} 
Ваги \\
пріоритетів
\end{tabular} & $K_{18}$ & $\begin{array}{c}\text { Ваги } \\
\text { пріоритетів } \\
\end{array}$ & & \\
\hline $\mathbf{A}_{1}$ & 0,25 & $\mathbf{A}_{1}$ & 0,3 & & \\
\hline $\mathbf{A}_{2}$ & 0,2 & $\mathbf{A}_{2}$ & 0,3 & & \\
\hline $\mathbf{A}_{3}$ & 0,2 & $\mathbf{A}_{3}$ & 0,2 & & \\
\hline $\mathbf{A}_{4}$ & 0,1 & $\mathbf{A}_{4}$ & 0,05 & & \\
\hline $\mathbf{A}_{5}$ & 0,05 & $\mathbf{A}_{5}$ & 0,05 & & \\
\hline $\mathbf{A}_{6}$ & 0,1 & $\mathbf{A}_{6}$ & 0,05 & & \\
\hline $\mathbf{A}_{7}$ & 0,1 & $\mathbf{A}_{7}$ & 0,05 & & \\
\hline
\end{tabular}

Значення пріоритетів альтернатив щодо фактору РИЗИКИ мають такий вигляд:

$\left.\left[\begin{array}{ccccc}0,05 & 0,2 & 0,2 & 0,25 & 0,3 \\ 0,05 & 0,2 & 0,2 & 0,2 & 0,3 \\ 0,10 & 0,05 & 0,2 & 0,2 & 0,2 \\ 0,15 & 0,13 & 0,2 & 0,1 & 0,05 \\ 0,35 & 0,14 & 0,05 & 0,05 & 0,05 \\ 0,20 & 0,13 & 0,10 & 0,1 & 0,05 \\ 0,10 & 0,15 & 0,05 & 0,1 & 0,05\end{array}\right] \times\left[\begin{array}{c}0,47 \\ 0,10 \\ 0,28 \\ 0,086 \\ 0,054\end{array}\right]=\left[\begin{array}{c}0,14 \\ 0,17 \\ 0,18 \\ 0,15 \\ 0,12 \\ 0,14 \\ 0,16\end{array}\right]_{A_{7}}^{A_{1}}\right]_{A_{2}}$

Таблиця 11. Значення факторів і відношення між ними

\begin{tabular}{|l|c|c|c|c|c|c|c|}
\hline \multirow{2}{*}{\multicolumn{1}{c|}{ Фактори }} & \multicolumn{7}{c|}{ Альтернативи } \\
\cline { 2 - 9 } & $\mathbf{A}_{\mathbf{1}}$ & $\mathbf{A}_{\mathbf{2}}$ & $\mathbf{A}_{\mathbf{3}}$ & $\mathbf{A}_{\mathbf{4}}$ & $\mathbf{A}_{\mathbf{5}}$ & $\mathbf{A}_{\mathbf{6}}$ & $\mathbf{A}_{\mathbf{7}}$ \\
\hline Вигоди & 0,04 & 0,038 & 0,011 & 0,085 & 0,28 & 0,30 & 0,25 \\
\hline Можливості & 0,02 & 0,08 & 0,15 & 0,13 & 0,23 & 0,26 & 0,20 \\
\hline Витрати & 0,05 & 0,05 & 0,02 & 0,15 & 0,23 & 0,30 & 0,20 \\
\hline Ризики & 0,14 & 0,17 & 0,18 & 0,15 & 0,12 & 0,14 & 0,16 \\
\hline Вигоди/Витрати & 0,8 & 0,76 & 0,55 & 0,57 & 1,2 & 1,0 & 1,25 \\
\hline Вигоди/Ризики & 0,28 & 0,22 & 0,06 & 0,56 & 2,3 & 2,14 & 1,56 \\
\hline Можливості/Витрати & 0,4 & 1,6 & 7,5 & 0,86 & 1,0 & 0,87 & 1,0 \\
\hline Можливості/Ризики & 0,14 & 0,47 & 0,83 & 0,87 & 1,77 & 1,86 & 1,25 \\
\hline ВосR = Вигоди х Можливості & 0,11 & 0,08 & 0,44 & 0,45 & 2,0 & 2,0 & 1,67 \\
\hline Витрати х Ризики & & & & & & & \\
\hline
\end{tabular}


На основі отриманих пріоритетів альтернатив (типів катерів і кораблів) сформуємо табл. 11, що характеризує значення факторів і різні види відношень між ними.

Розглянувши табл. 11, можна зробити висновок, що переважна кількість розрахункових показників вказує на домінування таких альтернатив, як: $\mathrm{A}_{5}-$ ракетний катер «Веспа», $\mathrm{A}_{6}$ й $\mathrm{A}_{7}-$ корвети «Гайдук» $\mathrm{i}$ «Каракал». Це означає, що відроджуваний флот повинен мати у своєму складі як катери, так і корвети, що забезпечить найбільш ефективне вирішення завдань обороноздатності морських рубежів.

\section{ВИСНОВКИ}

1. Вперше для вирішення завдання подальшого розвитку ВМС України використано підхід на основі ФОРСАЙТ-технологій. Отримані результати дозво- лили дійти висновку, що для найбільш ефективного вирішення завдань обороноздатності морських рубежів ВМС України повинні мати в своєму складі як катери, так і корвети. 2. Запропонований підхід може бути використаний для вирішення завдань оборонного будівництва в умовах наявних слабо структурованих проблем і невизначеностей. 3. Перспективи подальших досліджень пов'язані з розробкою спеціалізованої системи підтримки прийняття рішень та вдосконаленням інструментальних методів ФОРСАЙТ-технологій, що базуються на аналізі групових експертних оцінок, заснованих на сучасних теоріях (теорії свідоцтв Демпстера-Шейфера, теорії правдоподібних і парадоксальних міркувань Дезера-Смарандаке, теорії можливостей тощо) $[17,18]$, що дозволить оцінювати конфліктні ситуації в експертних судженнях.

\section{REFERENCES}

[1] Zgurovskij M. Z., Pankratova N. D. (2005) Tehnologicheskoe predvidenie. [Technological foresight]. Kiev : Politehnika. [in Russian]

[2] Zghurovskyi M. Z. (2015) Foresight of Ukrainian economy. Retrieved from: http://ied.kpi.ua/wp-content/uploads/2015/10/ Foresight2015.pdf

[3] Zghurovskyi M. Z. (2001) Systemna metodolohiia peredbachennia [System methodology of prediction]. Kyiv : Politekhnika. [in Ukrainian]

[4] Georghiou L. et al. (2009) Handbook of Technology Foresight: Concepts and Practice. Cheltenham : Edward Elgar.

[5] Popper R. (2008) How are foresight methods selected. Foresight, vol. 10(6). Retrieved from: https://www.researchgate.net/ publication/228678576_How_are_foresight_methods_selected_Foresight_106_62-89

[6] Saritas O., Gokhberg L., Sokolov A. (eds) (2013) Systemic Foresight Methodology. Science, Technology and Innovation Policy for the Future. Berlin, Heidelberg: Springer. DOI: https://doi.org/10.1007/978-3-642-31827-6_6

[7] The European Foresight Monitoring Network. (2008) Collection of EFMN Briefs. Part 1. Luxembourg: Office for Official Publications of the European Communities. Retrieved from: https://ec.europa.eu/research/social-sciences/pdf/other_pubs/ efmnreport_en.pdf

[8] Timinsky A. et al. (2019) Digitalisation HR-management Used Bi-adaptive and Foresight Models. CEUR Workshop Proceedings, vol. 2565, pp. 221-232. DOI: 10.1109/ATIT49449.2019.9030518.

[9] Tereshina N. P., Tret'jak V. P., Metelkin P. V. (2019) Forsajt tehnologii: uchebnoe posobie. [Foresight of technology: a tutorial]. Moskva : RUT (MIIT). [in Russian]

[10] Krjukov S. V. (2010) Forsajt: ot prognoza k formirovaniju budushhego. [Foresight: from forecasting to shaping the future]. Terra Economicus, vol. 8 (3-2), pp. 7-17. [in Russian]

[11] Saaty Thomas L. (2001) Fundamentals of Decision Making and Priority Theory. Pittsburgh, Pennsylvania : RWS Publications.

[12] Arroyo P., Tommelein I. D., Ballard G. (2015) Comparing AHP and CBA as Decision Methods to Resolve the Choosing Problem in Detailed Design. Journal of Construction Engineering and Management, no. 141(1). DOI: 10.1061/(ASCE) CO.1943-7862.0000915.

[13] Saaty Thomas L. (2009) Mathematical Principles of Decision Making (Principia Mathematica Decernendi). Pittsburgh : RWS.

[14] Stratehiia viiskovo-morskykh syl Zbroinykh syl Ukrainy-2035. (2019) [Strategy of the Naval Forces of the Armed Forces of Ukraine-2035]. Retrieved from: https://navy.mil.gov.ua/strategiya-vijskovo-morskyh-syl-zbrojnyh-syl-ukrayiny-2035

[15] Moskitnyj flot i perspektivy razvitija VMSU kak variant asimmetrichnogo otveta silam agresora (2017) [Mosquito Fleet and Prospects for the Development of the Naval Forces of Ukraine as a Variant of an Asymmetric Response to the Aggressor's Forces]. Retrieved from: https://dumskaya.net/news/moskitnyy-flot-i-perspektivy-razvitiya-vmsu-kak-071171

[16] Moskitnyj flot. Ukraina stroit voenno-morskie bazy. (2020) [Mosquito fleet. Ukraine is building naval bases]. Retrieved from: https://www.svoboda.org/a/ 30919369.html

[17] Kovalenko I., Davydenko Y., Shved A. (2019) Formation of Consistent Groups of Expert Evidences Based on Dissimilarity Measures in Evidence Theory. 2019 IEEE 14th International Conference on Computer Sciences and Information Technologies (CSIT), Lviv, Ukraine, pp. 113-116. DOI: 10.1109/STC-CSIT.2019.8929858.

[18] Shved A., Kovalenko I., Davydenko Y. (2020) Method of Detection the Consistent Subgroups of Expert Assessments in a Group Based on Measures of Dissimilarity in Evidence Theory / Shakhovska N., Medykovskyy M. (eds). Advances in Intelligent Systems and Computing IV. CCSIT 2019. Advances in Intelligent Systems and Computing, vol 1080. Springer, Cham. pp. 36-53. DOI: 10.1007/978-3-030-33695-0_4. 


\section{КОМП'ЮТЕРНІ НАУКИ ТА ІНФОРМАЦІЙНІ ТЕХНОЛОГІЇ № З 2021}

\section{СПИСОК ВИКОРИСТАНОЇ ЛІТЕРАТУРИ}

[1] Згуровский М. З., Панкратова Н. Д. (2005) Технологическое предвидение. Киев : Политехника.

[2] Zghurovskyi M. Z. (2015) Foresight of Ukrainian economy. URL: http://ied.kpi.ua/wp-content/uploads/2015/10/ Foresight2015.pdf

[3] Згуровський М. 3. (2001) Системна методологія передбачення. Київ : Політехніка.

[4] Georghiou L. et al. (2009) Handbook of Technology Foresight: Concepts and Practice. Cheltenham : Edward Elgar.

[5] Popper R. (2008) How are foresight methods selected. Foresight, vol. 10(6). URL: https://www.researchgate.net/ publication/228678576_How_are_foresight_methods_selected_Foresight_106_62-89

[6] Saritas O., Gokhberg, L., Sokolov, A. (eds) (2013) Systemic Foresight Methodology. Science, Technology and Innovation Policy for the Future. Berlin, Heidelberg : Springer. DOI: 10.1007/978-3-642-31827-6_6.

[7] The European Foresight Monitoring Network. (2008) Collection of EFMN Briefs. Part 1. Luxembourg : Office for Official Publications of the European Communities. URL: https://ec.europa.eu/research/social-sciences/pdf/other_pubs/ efmnreport_en.pdf

[8] Timinsky A. et al. (2019) Digitalisation HR-management Used Bi-adaptive and Foresight Models. CEUR Workshop Proceedings, vol. 2565, pp. 221-232. DOI: 10.1109/ATIT49449.2019.9030518.

[9] Терешина Н. П., Третьяк, В. П., Метелкин, П. В. (2019) Форсайт-технологии : учебное пособие. Москва : РУТ (МИИТ)

[10] Крюков С. В. (2010) Форсайт: от прогноза к формированию будущего. Terra Economicus. Т. 8. № 3. C. 7-17.

[11] Saaty Thomas L. (2001) Fundamentals of Decision Making and Priority Theory. Pittsburgh, Pennsylvania : RWS Publications.

[12] Arroyo P.; Tommelein, I. D.; Ballard, G. (2015) Comparing AHP and CBA as Decision Methods to Resolve the Choosing Problem in Detailed Design. Journal of Construction Engineering and Management. No. 141(1). DOI: 10.1061/(ASCE) CO.1943-7862.0000915.

[13] Saaty Thomas L. (2009) Mathematical Principles of Decision Making (Principia Mathematica Decernendi). Pittsburgh : RWS.

[14] Стратегія Військово-морських сил Збройних сил України-2035. (2019). URL: https://navy.mil.gov.ua/ strategiya-vijskovo-morskyh-syl-zbrojnyh-syl-ukrayiny-2035

[15] Москитный флот и перспективы развития ВMCУ как вариант асимметричного ответа силам агресора. (2017). URL: https://dumskaya.net/news/moskitnyy-flot-i-perspektivy-razvitiya-vmsu-kak-071171

[16] Москитный флот. Украина строит военно-морские базы. (2020). URL: https://www.svoboda.org/a/ 30919369.html

[17] Kovalenko I., Davydenko Y., Shved A. (2019) Formation of Consistent Groups of Expert Evidences Based on Dissimilarity Measures in Evidence Theory. 2019 IEEE 14th International Conference on Computer Sciences and Information Technologies (CSIT). Lviv, Ukraine, pp. 113-116. DOI: 10.1109/STC-CSIT.2019.8929858.

[18] Shved A., Kovalenko I., Davydenko Y. (2020) Method of Detection the Consistent Subgroups of Expert Assessments in a Group Based on Measures of Dissimilarity in Evidence Theory / Shakhovska N., Medykovskyy M. (eds). Advances in Intelligent Systems and Computing IV. CCSIT 2019. Advances in Intelligent Systems and Computing, vol. 1080. Springer, Cham. pp. 36-53. DOI: 10.1007/978-3-030-33695-0_4

(c) Фаріонова Т. А., Коваленко І. І., Швед А. В., Давиденко С. О. Дата надходження статті до редакції: 17.09.2021 p. Дата затвердження статті до друку: 04.10.2021 p. 